\title{
Knowledge of parents regarding newborn screening test, after accessing the website "Babies' Portal" - Heel prick test
}

\section{Conhecimento de pais quanto a triagem neonatal, contribuição do website Portal dos Bebês - Teste do pezinho}

Caroline Antonelli Mendes ${ }^{(1)}$

Amanda Perantoni Guigen ${ }^{(1)}$

Fernanda da Luz Anastácio-Pessan ${ }^{(1)}$

Jeniffer de Cássia Rillo Dutka (2)

Dionísia Aparecida Cusin Lamônica(2)

\section{(1) Universidade de São Paulo. \\ (2) Departamento de Fonoaudiologia da Faculdade de Odontologia de Bauru da Universidade de São Paulo.}

Conflict of interest: non-existent
Received on: July 20, 2016 Accepted on: June 19, 2017

Mailing address:

Caroline Antonelli Mendes

Rua Olímpio de Macedo, n. 02045, Ap. 06

Vila Universitária, Bauru- São Paulo

CEP: $17012-533$

E-mail: caroline.mendes@usp.br

\section{ABSTRACT}

Purpose: to assess the knowledge of mothers about the heel prick test, develop contents on this test to make it available on the "Babies' Portal" website, evaluate and validate the informative material developed.

Methods: this study was conducted in three stages, that is, the first stage which is about a descriptive study involving 105 mothers of newborn children before performing the neonatal screening "Heel Prick Test", the second one consisting in the development of the website "Babies' Portal", and the third stage, the evaluation and validation of this material carried out by 20 parents of children between zero and 36 months old, who underwent the neonatal screening Heel Prick Test by accessing the website "Babies' Portal".

Results: although the interviewed mothers knew that their children had the right to be tested, they showed no knowledge of the diseases that can be prevented, time of diagnosis, nor the consequences arising from the lack of early diagnosis and treatment. The website creation and validation gathered basic information about the Heel Prick Test, and the participants regarded the content from satisfactory to excellent.

Conclusion: it is necessary that families know not only about the procedures their children will undergo, but also the reason they are performed and the consequences of failing in doing so.

Keywords: Neonatal Screening; Inborn Errors of Metabolism; Telemedicine

\section{RESUMO}

Objetivo: verificar conhecimento de mães sobre o Teste do Pezinho, desenvolver conteúdos sobre este teste" para disponibilizar no website "Portal dos Bebês", avaliar e validar o material informativo desenvolvido.

Métodos: este estudo foi realizado em três fases. A primeira trata-se de um estudo descritivo com a participação de 105 mães de crianças recém-nascidas, antes de realizar a triagem neonatal "Teste do Pezinho". A segunda consistiu da elaboração de um website no site "Portal dos Bebês" e na terceira fase foi realizada a avaliação e validação deste material por 20 pais de crianças, com idades entre zero a trinta e seis meses, que realizaram a triagem neonatal, Teste do Pezinho, por meio do acesso ao site "Portal dos Bebês".

Resultados: apesar das mães entrevistadas saberem que os filhos têm direito à realização do Teste, não demonstraram conhecimento acerca das doenças que podem ser prevenidas, época do diagnóstico, as sequelas advindas da falta do diagnóstico e tratamento precoce. A criação e validação do website reuniu as informações básicas a respeito do Teste do Pezinho e os conteúdos foram avaliados como satisfatórios a excelente pelos participantes.

Conclusão: é necessário que as famílias tenham o conhecimento não somente dos procedimentos a que irão submeter os seus filhos, mas o porquê de estarem realizando-os, e as consequências, caso não 0 façam.

Descritores: Triagem Neonatal; Erros Inatos do Metabolismo; Telemedicina 


\section{INTRODUCTION}

The public health program "TP" (Teste do Pezinho, Neonatal Heel Prick Test) is part of PNTN (Programa Nacional de Triagem Neonatal, National Newborn Screening Program), implemented on 2001 by Ordinance No. 822 of $06 / 06 / 01$ of the Ministry of Health $^{1,2}$, which determines the gratuity and obligatoriness of the tests for neonatal diagnosis of several diseases by the Unified Health System ${ }^{3}$. The newborn screening test $(\mathrm{TN})^{2,3}$ is a preventive action in order to conduct the diagnosis, as early as possible, of several congenital or infectious diseases that are asymptomatic in the neonatal period. TN is intended to interfere on the course of the disease, thus allowing for specific early treatment and mitigation or elimination of sequelae associated with each disease ${ }^{4,5}$. The PNTN covers, in addition to examinations and detection of diseases, the monitoring and treatment of patients, often for the lifetime $e^{2,3,6,7}$.

The diseases covered by TP are Congenital Hypothyroidism ( $\mathrm{CH}$ ), Phenylketonuria (PKU), Sickle Cell Disease (SCD) and Cystic Fibrosis (CF). CH is a systemic metabolic disorder due to insufficient production of thyroid hormones due to thyroid gland malformation or disturbance in hormonal biosynthesis. It is a hereditary disease that, if left untreated, seriously compromises intellectual growth and development, since it is considered one of the few causes of intellectual disability that can be prevented when diagnosed and treated early ${ }^{5,8}$.

PKU refers to the autosomal recessive metabolic disorder. It results from mutation of the gene located on chromosome 12q22-24.1, associated with intellectual relegation, hyperactivity, tremor, microcephaly, growth failure, agitated behavior, autistic behavior and / or conduct disorder and seizure. When PKU is diagnosed and treated early, and with continuous treatment, severe neurological deterioration and intellectual disability are avoided ${ }^{7,9}$.

SCD is the most common genetic alteration worldwide, ${ }^{10}$ and in our country. It is a very severe chronic hemolytic disease, with autosomal recessive inheritance, and major clinical variability in Afro-descendants ${ }^{11,12}$. Among SCD types, Sickle Cell Anemia (SCA) is the most frequent including manifestations such as hemolytic anemia and bacterial infection. The symptoms appear between four and six months old, including child's irritability, continuous crying, lack of appetite, swelling in the hands and feet, stiffness and pain in the joints, in addition to subsequent painful crises $^{10}$. Neurological complications can be caused by stroke, transient ischemic attacks (TIA) or silent cerebral infarctions ${ }^{13}$. Children may present signs of delayed growth, skeletal deformities, low weight, retinopathy, skin ulcers, stroke and increased susceptibility to infections ${ }^{11}$.

CF is a genetic (autosomal recessive) disorder characterized by chronic airway infections, leading to the development of bronchiectasis, exocrine pancreatic insufficiency and intestinal dysfunctions, sweat gland abnormalities, and genitourinary dysfunction. In the latter stages of the disease, pancreatic endocrine dysfunction gives rise to diabetes mellitus. CF has a very high morbidity and mortality, with only $34 \%$ of patients reaching adulthood ${ }^{14,15}$.

Since most diseases diagnosed by TP do not show symptoms soon after birth, it is essential that the family seek medical attention upon suspected cases, since the risk is to engender serious and irreversible sequelae in the development of the child, which will only be perceived late. The lack of information may negatively affect the test performance, compromising the early diagnosis, the beginning of the treatment and its continuity. Brazilian research carried out along with the PNTNs identified mothers and relatives not aware about TP ${ }^{16-20}$.

Health Education constitutes a set of knowledge and practices oriented towards disease prevention and health promotion ${ }^{21,22}$ which can be implemented through Distant Learning (DL) ${ }^{23}$. The digital accessibility opens paths and brings opportunities which allow access to digital content ${ }^{24}$, being an important strategy / tool for the dissemination of knowledge ${ }^{25}$. The effectiveness of Health Education in the digital environment has been implemented through websites that provide created and validated materials. The quality of digital teaching strategies, such as websites, for instance, is critical to the legitimacy and credibility of these tools, in order to truly foster knowledge for users, affecting therefore on the life quality of families and their children ${ }^{26}$.

This study consisted of three objectives: check the awareness of mothers regarding TP; develop content around the "Heel Prick Test" and make it available on the website "Babies' Portal" and evaluate and validate the information material developed.

\section{METHODS}

The study was conducted in three phases and was approved by the Human Research Ethics Committee 
of the Bauru School of Dentistry from the University of São Paulo (Protocols 116/2007, 138/2011 and 05051112.0.0000.5417). All the participants involved signed the "Free and Informed Consent Term", following the criteria of the National Council of Research Ethics (CONEP).

\section{First Stage Procedures}

In order to check the mother awareness of the TP, before developing the material on this topic, 105 mothers of newborns who had their children on public maternity hospitals (tied to the Unified Health System - SUS) were invited to join the first stage of this study. The inclusion criteria were: being primiparous; in the postpartum bed period and answering to the questionnaire of the first stage of this study, before their infant are submitted to "TP". The questionnaire applied at this stage (Questionnaire 1) included the following four questions: Do you know or have you ever heard of "Heel Prick Test" (TP)? What is the purpose of TP? At what time should the TP exam be performed? Also, do you know what diseases can be diagnosed with this test? The exclusion criteria were: not being primiparous or not interested in participating in the study.

\section{Second Stage Procedures}

The purpose of the second stage was creating the content around the TP in order to provide it on the website. After obtaining the data from the first stage, a literature and website review was conducted around the subject in order to identify the content that should be addressed, including a description of the main diseases screened by the TP. The material was divided into 7 modules: Module 1: What is the Heel Prick Test; Module 2: When to perform the Test of the Pezinho; Module 3: How the test is performed; Module 4: Congenital Hypothyroidism; Module 5: Phenylketonuria; Module 6: Cystic fibrosis; and Module 7: Sickle Cell Disease. In addition to texts narrating the information proposed by the modules, videos of interviews with health professionals (a pediatric doctor and a biologist) with PNTN expertize were incorporated. After preparing the material, it was posted at http:// portaldosbebes.fob.usp.br.

\section{Third Stage Procedures: Material Evaluation by Professionals}

Ten professionals working in the healthcare area were initially invited to verify the accessibility and quality of the material in terms of design and content. They were oriented to access the site: http://portaldosbebes.fob.usp.br, select an option "Speech Therapy", at option: "Teste do Pezinho", read and view all seven modules of the material. A period of 10 days was given so the professionals could write an e-mail to the responsible researcher regarding the quality of the material, with answers to the following questions: - Regarding the website visualization, was it possible to access all modules and open all videos?; - As for the Font settings, was it set to the same size and justified?; - What are the suggestions for word substitution in order to facilitate the content understanding while reading the text? A blank space was available for them to write down their considerations, suggestions and critiques.

After the adjustments on the website with the professionals' suggestions, the researchers selected 20 mothers of children up to 36 months old, divided into two groups: Group 1 (G1) included mothers of babies who were born in public maternity hospitals and Group 2 (G2) included mothers of babies who were born in a private hospital. Initially, in the presence of the responsible researcher, all mothers answered a questionnaire with twelve questions regarding the socioeconomic status, in order to profile the interviewees with the following data: number of children, how old are the youngest child, if she works and what is her job, education, marital status, internet use frequency and the speed of connection. Subsequently, the participants were invited to answer a questionnaire twice about the modules content of the developed material: the first time before accessing the material and the second time after accessing the material. The questionnaire was based on previous experience of the researchers, which were based on published studies ${ }^{27-29}$.

They were asked about what is TP; the ideal period to perform the TP; how the test is performed; what is the purpose of the test (descriptive form); why is necessary to perform the test; which diseases are screened by TP; and an evaluation after obtaining test information. In this evaluation, the participant could rate the website within a scale with the following options: very bad, bad, satisfactory, good and very good.

The mothers who agreed to participate on the study received an envelope containing: the Free and Informed Consent Term (with explanations about the study), the questionnaire, and guidelines on how to access the material using their own computers. After answering the questionnaire, participants were asked to access the site: http://portaldosbebes.fob.usp.br. 
select the option "Speech Therapy"29, select the option "Heel Prick Test", and read all 7 modules of the material about TP. A period of 30 days was given for the participant to access the material on her own computer.

After accessing it, mothers were once again asked to respond to the questionnaire about the content and to use a form to evaluate the content on the website. The evaluation of the presentation and ease of using the software (view and execution) consisted of seven questions, which related to information visualization and software execution. Questions were asked about screen presentation, how much information was available on the screen, how easy it was to explore the items and features available, such as how easy it was to explore the content, watch videos, and how appropriate it was to the target audience. A four-point scale was used to assign a score to the material: unsatisfactory, reasonable, satisfactory or excellent.

The unsatisfactory score should be selected in case mothers judged that the material was unable to meet the goals of raising awareness about TP. The reasonable score should be assigned if they felt that the material, although informative, had failed to present relevant information on the topic addressed. The satisfactory score should be assigned in case mothers judged that the material brings relevant contributions on the TP, but could be improved based on suggestions. The excellent score should be assigned in case mothers judged that the material, in addition to bringing relevant contributions on the subject, would not require modifications as to content or form. The participants also had a blank space to write their considerations, suggestions and critiques.

The criteria used to evaluate the dissertation questions about the diseases mentioned on the website were: to be considered a complete question it would require more than two information provided (described) on the website, i.e. the text of each sub item contains more than three information; however, the information considered incomplete consisted of only one characteristic of the disease. The results were organized in a database for later statistical analysis.

\section{RESULTS}

\section{First Stage Results}

The average age of participants ranged from 14 to 44 years old. As to education, $8 \%$ had completed an university degree and $3 \%$ had an incomplete degree; $20 \%$ completed high school and $20 \%$ did not complete high school, 33\% completed elementary school and $16 \%$ did not complete elementary school. All mothers were SUS users. The results of the questionnaire applied in the first stage revealed that, while $100 \%$ of mothers had heard about TP at the time they answered the questionnaire, $1.98 \%$ did not know which diseases are screened by this test; $89 \%$ did not know the purpose of the TP; and $30 \%$ were unable to indicate the time at which TP should be performed.

The data obtained in the first stage of this study corroborated findings from previous studies that identified the lack of knowledge by the mothers and relatives about $\mathrm{TP}^{16-20}$. Considering that disinformation may negatively influence the performance of this screening, compromising both the early diagnosis and the beginning of treatment and its continuity, the second stage of this project was implemented with the objective of developing a material regarding TP for dissemination on the website "Babies' Portal".

\section{Results of the Second Stage}

The developed material was posted at http://portaldosbebes.fob.usp.br. The conventional stages for the development of instructional material were followed, considering the thematic analysis, planning, design and development, implementation and evaluation ${ }^{30}$. The Babies' Portal is a website hosted by the Bauru Faculty of Dentistry on which materials for parents and caregivers are available on two knowledge fields: Speech Therapy and Dentistry. The Babies' PortalFonoaudiologia, more specifically, includes information, texts, videos and illustrations on various areas, regarding the development of communication and chewing and swallowing functions that occur on the 0-3 age group.

Among the several themes, the material developed in this study was included in the portal. Access the following address to view the material developed on the second stage of this study: http://portaldosbebes.fob.usp.br/portaldosbebes/ Portugues/ detSubCategorialnstitucional.php?codsubcategoria fono $=10033 \&$ codcategoria_site $=1$.

The third stage of this study was conducted with the objective of evaluating and validating the TP material made available at "Babies' Portal". This stage was carried out in two steps: initially, professionals working with the TP assessed the accessibility and quality of the material developed and in a later time, a group of mothers was invited to evaluate the material. 


\section{Results of the Third Stage}

The information gathered from the comments and dissertation questions were treated qualitatively, so it was necessary to verify the suggestions and critiques presented by the professionals.

Adjustments were made according to the professionals' comments to the website in terms of formatting (font size and color and text justification) and configuration of content (language suitability making the narrative more accessible to all readers).
On the Material evaluation by Mothers, the age of G1 participants ranged from 21 to 49 years old and G2 ranged from 20 to 35 years old. As for the education degree, in G1 15\% had completed high school and 15\% had not; $40 \%$ did not complete college and $15 \%$ did. As for the education degree, in G2 30\% had completed high school; $40 \%$ did not complete higher education and $30 \%$ did.

Table 1 is related to the calculation of the average of the G1 and G2 answers to the questionnaire. It presents the participants' knowledge about the TP.

Table 1. Result of correct answers in \% of Group 1 and Group 2 on the first and second stage

\begin{tabular}{ccccc}
\hline Questionnaire & \multicolumn{2}{c}{ 1st Stage } & \multicolumn{2}{c}{ 2nd Stage } \\
\cline { 2 - 5 } & G1 & G2 & G1 & G2 \\
\hline Knowledge about TP & 70 & 100 & 90 & 100 \\
Age for performing the TP & 0 & 20 & 60 & 90 \\
Knowledge about PKU & 0 & 20 & 50 & 90 \\
Knowledge about CH & 0 & 0 & 60 & 90 \\
Knowledge about SCA & 0 & 0 & 60 & 80 \\
\hline
\end{tabular}

Caption: TP = Heel prick test; PKU = Phenylketonuria; $\mathrm{CH}=$ Congenital Hypothyroidism; SCA = Sickle Cell Anemia; G1 = Group 1; G2 = Group 2

When calculating the average from $\mathrm{G} 1$ and $\mathrm{G} 2$ participants answers on the categories overall satisfaction and website recommendation, the results is that $60 \%$ of $\mathrm{G} 1$ and $40 \%$ of G2 classified the website as excellent, $40 \%$ of $\mathrm{G} 1$ and $60 \%$ of $\mathrm{G} 2$ classified as satisfactory and all participants (100\%) recommend the website.

Figure 1 is related to the average calculation of participants' answers from groups $\mathrm{G} 1$ and $\mathrm{G} 2$ in order to verify the website satisfaction.

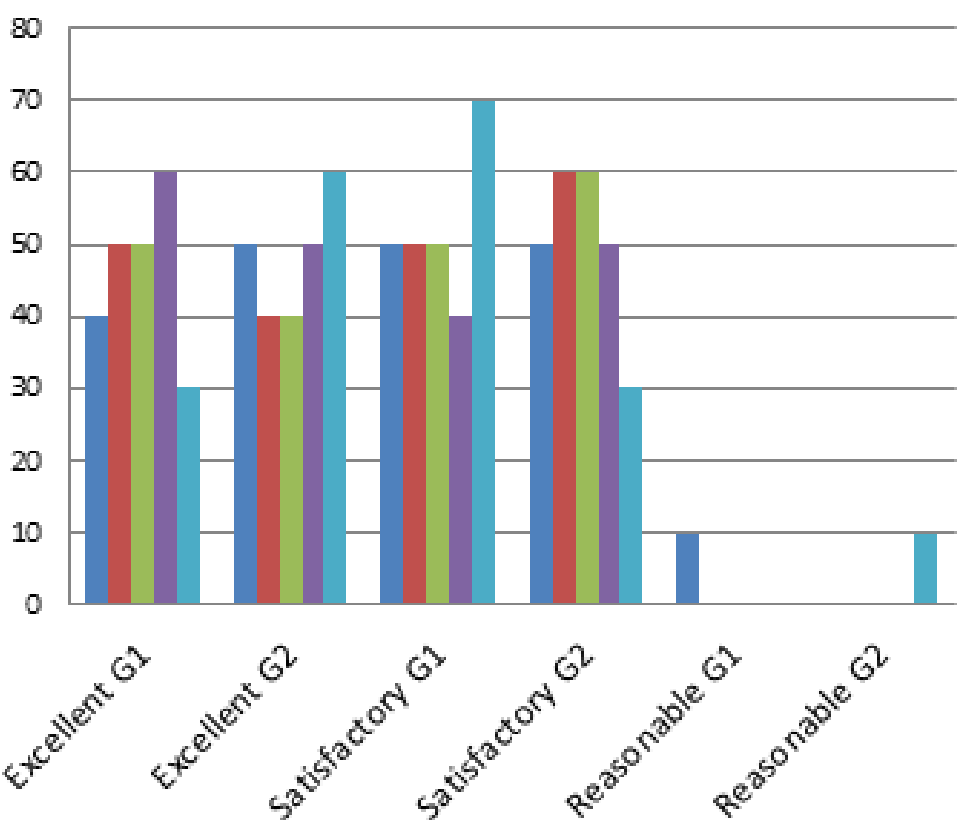

Content quality

Presentation

Amount of information

- Vocabulary

Type of Navigation

Figure 1. Categories average: content quality, presentation, amount of information, vocabulary and Type of Navigation, assessed by Group 1 and Group 2 
For the qualitative analysis, it was necessary to verify the suggestions and critiques presented by the evaluators, considering each group (G1 and G2). Below are the sentences inserted in the space for "suggestions" (question 28) from the questionnaire used by the evaluators, separated by their groups:

- G1: P4: "The video sound was very low, but it could be my computer." P8: "So far I was not aware of the website. It should be more publicized." P10: "The sound is low".

- G2: P1: "The item "Sickle Cell Disease" 'is not enlightening with regard to sickle cell anemia." P4: "The interview with the pediatrician is noisy (children screaming on the background). Regarding the explanation of Phenylketonuria, it is necessary to explain what happened with blood." P7: "Every time I wanted to see the content I had to return to the home page, the website could be more interactive, also it presents 'trembling language' and few 'figures'." P9: 'When clicking on the Heel Prick Test it should open another window with the information to be accessed rather than clicking at the Heel Prick Test every time to be able to access each of the explanations." P8: "It should be more detailed regarding the pathophysiology of the disease and be presented as follows: 1- pathophysiology, 2signs and symptoms and 3- treatment".

Table 2. Suggestions and numbers of occurrences of suggestions for the categories: content, visualization, execution and general, presented by Group 1 and Group 2

\begin{tabular}{|c|c|c|}
\hline G1 & $\begin{array}{c}\text { Content } \\
\text { Visualization } \\
\text { Execution } \\
\text { General } \\
\end{array}$ & $\begin{array}{l}\text { Difficulty in listening to videos ( } 2 p) \\
\text { Raise awareness of the website (1p) }\end{array}$ \\
\hline G2 & $\begin{array}{c}\text { Visualization } \\
\text { Execution } \\
\text { General }\end{array}$ & $\begin{array}{l}\text { Include video content on phenylketonuria (1p). } \\
\text { Divide the contents into: pathophysiology of the disease (1p) } \\
\text { Difficulty in reading (trembling screen) (1p). } \\
\text { Add pictures (1p) } \\
\text { Open a Heel prick test window so it is not necessary returning to the home page (1p) }\end{array}$ \\
\hline
\end{tabular}

Caption 2. P: People.

\section{DISCUSSION}

The right to health is a basic premise in the exercise of citizenship. Newborn screening test programs, related to the PNTN, recommend that every child born in the national territory shall be subjected to this preventive procedure, as provided by law ${ }^{1-3}$. It has been found that $100 \%$ of the mothers interviewed had already heard about TP and $70 \%$ knew that, upon leaving the maternity ward, they would have a schedule for the test for their children. Although the interviewed mothers were aware that their children have the right to TP, only $11 \%$ said that this test is a prevention procedure and only $2 \%$ showed knowledge about the preventable diseases.

Brazilian studies with similar objectives identified the lack of knowledge of mothers and their relatives about TP ${ }^{16-20}$, reporting that the majority of the parents / relatives who sought the service to perform the TP were not aware of its purpose and the pathologies that could be identified, as well as the possibility preventing sequelae when the diagnosis is made early and the treatment initiated before the onset of symptoms.

The disinformation by the parents can influence directly or indirectly on conducting the TP in a timely manner, thus affecting the life quality of the children and their families. It is evident, therefore, that health education should be directed towards the family, especially to the parents. One study ${ }^{17}$ showed that all the interviewed puerperae had the prenatal care, but they were not informed about the guidelines on the PNTN. They emphasized the importance of providing the information in prenatal care phase, since during this period the subject is able to assimilate the guidelines, and the prenatal care is the ideal moment for the pregnant woman to understand, process and learn 
about neonatal care and specially guidelines on ways to prevent injuries to both women and children.

As reported in the course of this study that, although TP is a right to every Brazilian newborn ${ }^{1,2}$, it was found that the baby family members are aware of the need to perform the test, usually scheduled before the maternity leave, but they do not always have the knowledge about the test, nor the screened diseases. Early diagnosis and knowledge of the diseases may increase the number of families adhering to treatment ${ }^{4-6,9-11,15}$.

According to Brazilian legislation, Distant Learning is a teaching modality that enables self-learning and promotes the empowerment of society with knowledge. However, the quality of the material offered must always be checked in order to have product accessibility and usability ${ }^{26}$. Thus, accessibility consists of considering the diversity of users and the peculiarities around the interaction of these people with the product, which can be manifested both in user preferences and in the quality restrictions of the used equipment, or even in the existence of special educational needs, which cannot be ignored by individuals developing products of this nature.

Accessibility and usability are features that add quality to a product, such as a course or information that is of interest to a particular population ${ }^{27,30}$. The material produced with this theme, which is on the website, has limitations on usability since it is necessary for the user to be literate and have access to a computer. It should be emphasized, however, that professionals working with this population could also be users of this tool and share this information with other families. The spread of the internet is fundamental for distant learning, since it allows the availability of information with multimedia resources and wide access and low cost. It is possible to reach remote locations and include a diverse range of people through the web, besides allowing time and space flexibility, improving or updating the individual, respecting the user rhythm, with the possibility of access being carried out at home or in the workplace.

Regarding the suggestions on the content, it has been observed that one G1 participant had doubts about the information around SCA, and in one G2 participant also suggested that the information was given in video format and another participant suggested providing more technical information on pathophysiology. As presented, the use of an easy-to-understand language was intended, being accessible to the target audience with scientific language that could be part of the family and professional repertoire. It should be emphasized, as observed in the descriptive analysis, that all participants reported understanding the language used for the materials on the Babies' Portal.

As for the items execution and visualization, it was found that the difficulties could be related to the equipment of the user. Regarding the suggestion for a proper window in order to open the themes without having to return to the home page, it is an important recommendation that will be enabled for the on line version.

The material evaluation by the users is of great importance for the improvement of the information considering the user's needs. Several studies that gauge the population's acceptance of telehealth were approved by the user ${ }^{27-30}$.

The validation is essential to develop more methods that can help in the dissemination of the topic addressed: The Heel Prick Test - since the lack of knowledge from the family regarding these diseases can affect directly or indirectly on the accomplishment of the screening compromising the diagnosis, the beginning of early treatment, as well as the disease follow-up.

\section{CONCLUSIONS}

Orienting mothers about preventive procedures for diseases predicted by the "TP" may stimulate behaviors aimed to reduce the risk and vulnerability conditions for changes in child development, preventing irreversible sequelae. Informative actions are necessary for society given the relevance of this knowledge, contributing to the active participation on child health programs offered by the PNTN.

The website conception is of great relevance; since it gathers basic information about the Heel Prick Test, allowing access to the guidelines when necessary. Thanks to this work, anyone can have access to this type of information at http://portaldosbebes.fob.usp. $\mathrm{br}$, which was rated as satisfactory to excellent by the participants. After the website creation and elaboration, a layout issue occurred in 2013 and for this reason it was necessary to make some changes in formatting, font size and color, which demanded most of the time, since the website presented formatting issues. The content was organized into topics with illustrations and videos. The evaluation process by the participants was effective in assessing the quality of the material and achieving the established goal: to promote information about the Heel Prick Test. 
The complementation of theoretical contents with visual and auditory information are crucial strategies for arranging the contents of distance learning. The combination of these different features on the content propagation helps in the teaching-learning process, since the information load becomes significantly greater as the sensorial appeals are multiplied, favoring attention and learning.

With greater level of knowledge by the population on the subject, it is possible to assist them to recognize the importance of prevention procedures in the lives of children along with the diseases screened by the Heel Prick Test, as well as the beginning of the early treatment relevance to avoid the deleterious effects of diseases on infant development.

\section{ACKNOWLEDGEMENTS}

We would like to thank the parents and caregivers who promptly proposed to participate in this research, the Coordination of the University of São Paulo, the Maternity Santa Isabel and the students of the Speech Therapy Course of USP based on Bauru who were present during the activities involved in this project.

\section{REFERENCES}

1. Manual de Normas Técnicas e Rotinas do Teste de Triagem Neonatal, Faculdade de Medicina de Ribeirão Preto, 2011. Available at: http://www. hcrp.fmrp.usp.br/sitehc/upload\%5CMANUAL\%20 DE\%20INSTRU\%C3\%87\%C3\%95ES\%20DO\%20 TESTE\%20DO\%2OPEZINHO\%202011.pdf. [Access on February 12, 2013].

2. Brasil. Ministério da Saúde. Manual de normas técnicas e rotinas operacionais do programa nacional de triagem neonatal. [Internet homepage] Brasília: Ministério da Saúde; 2002. [Access on July 23, 2010] Available at: URL: http:/www.saude.gov. br/sas.

3. Brasil. Ministério da Saúde. Manual de normas técnicas e rotinas operacionais do programa nacional de triagem neonatal, $2^{\mathrm{a}}$ edição ampliada, Brasília, Ministério da Saúde, 2004. [Access on July 23, 2010] Available at: URL: http://bvsms.saude. gov.br/bvs/publicacoes/triagem_neonatal.pdf

4. Mak CM, Lee,HC, Chan AY, Lam CW. Inborn errors metabolism and expanded newborn screening: Review and update. Crit Rev Clin Lab Sci. 2013;50(6):142-62.
5. Ford G, La Franchi SH. Screening for congenital hypothyroidism: a world wide view of strategies. Best Pract Res Clin Endocrinol Metab. 2014;28(2):175-87.

6. Wassner AJ, Brown RS. Hypothyroidismin the new born period. Curr Opin Endocrinol Diabetes Obes. 2013;20(5):449-54.

7. Alhafid N, Christodoulou J. Phenylketonuria: a review of current and future treatments. Transl Pediatr. 2015;4(4):304-17.

8. Uyttendaele M, Lambert S, Tenoutasse S, Boros E, Ziereisen F, Van Vliet $G$ et al. Congenital Hypothyroidism: Long-Term Experience with Early and High Levothyroxine Dosage. Horm Res. Paediatr. 2016;85(3):188-97.

9. Strisciuglio $P$, Concolino D. New Strategies for the Treatment of Phenylketonuria (PKU). Metabolites. 2014;4(4):1007-17.

10. Boulet SL, Yanni ES, Creary MS, Olney RS. Health Status and Healthcare Use in a National Sample of Children with Sickle Cell Disease. Am J Prev Med. 2010;38(4S):S528-S535.

11. De Baun MR, Sarnaik SA, Rodeghier MJ, Minniti CP, Howard TH, lyer RV et al. Associated risk factors for silent cerebral infarcts in sickle cell anemia: low baseline hemoglobin, sex, and relative high systolic blood pressure. Blood. 2012;119(16):3684-90. doi: 10.1182/blood-2011-05-349621. Epub 2011 Nov 17.

12. Lawrence C, Webb J. Sickle Cell Disease and Stroke: Diagnosis and Management. Curr Neurol Neurosci Rep. 2016;16(3):27.

13. Kato GJ. New insights into sickle cell disease: mechanisms and investigational therapies. Curr Opin Hematol. 2016;23(3):224-32. doi: 10.1097/ MOH.0000000000000241.

14. Okumura MJ, Kleinhenz ME. Cystic Fibrosis Transitions of Care: Lessons Learned and Future Directions for Cystic Fibrosis. Clin Ches Med. 2016;37(1):119-26

15. Kumar S, Tana A, Shankar A. Cystic fibrosis: what are the prospects for a cure? Eur J Intern Med. 2014;25(9):803-7.

16. Abreu IS, Braguini WL. Triagem neonatal: o conhecimento materno em uma maternidade no interior do Paraná, Brasil. Rev Gaúcha Enferm. 2011;32(3):596-601.

17. Santos EC, Gaíva MAM, Santos JG, Abud SM. O conhecimento de puérperas sobre a triagem neonatal. Cogitare Enferm. 2011;16(2):282-8. 
18. Delvivo EM, Nazareth JB, Salvador M, Salimena, AMO, Dias IMAV. Teste do pezinho: desvelando o conhecimento das mães sobre o exame. HU Revista. 2012;38:45-50.

19. Acosta DF, Strefling ISS, Gomes VLO. Neonatal screening: (re)thinking nursing practice tamizaje neonatal: Rev Enferm UFPE [Internet journal]. 2013 [Access on: January, 2015]; 7(2): [572-8]. Available at: ' 'revistas.ufpr.br/cogitare/article/ download/35928/22407".

20. Silva FR, Ferreira AS, Melo DAN, Barros MMA. Avaliação do conhecimento das gestantes sobre a triagem neonatal. Revista Inter Texto. 2014;1:1-15.

21. Castaño PM, Stockwell MS, Malbon KM. Using digital technologies to improve treatment adherence. Clin Obstet Gynecol. 2013;56(3):434-45.

22. Roett MA, Coleman MT. Practice improvement, part II: update on patient communication technologies. FP Essent. 2013;414:25-31.

23. Alves L. Educação à distância: conceitos e história no Brasil e no mundo. RBAAD. 2011;10(7):83-92.

24. França LRDC. A Educação A Distância No Contexto Estrutural Do Capitalismo. REHUTEC. 2011;1(1):0.

25. Mori S, Whitaker IY, Marin HF. Estratégias tecnológicas de ensino associadas ao treinamento em Suporte Básico de Vida. Acta Paul Enferm. 2011; 24(5):721-5.

26. Bittencourt HR, Creutzberg M, Rodrigues ACM, Casartelli AO, Freitas ALS. Desenvolvimento e validação de um instrumento para avaliação de disciplinas na educação superior. Est Aval Educ [Internet journal] 2011 [access on April 23, 2016]; 22(48): [91-113]. Available at: http:// educa.fcc.org. br/pdf/eae/v22n48/v22n48a06.pdf

27. Oliveira AN. Ensino a Distância: elaboração de um CDROM para a capacitação de professores quanto à comunicação Humana e seus distúrbios. 2009. [Dissertação] Bauru (SP): Faculdade de Odontologia de Bauru, Universidade de São Paulo; 2009.

28. Campos K, Oliveira JRM, Blasca WQ. Processo de adaptação de aparelho de amplificação sonora individual: elaboração de um DVD para auxiliar a orientação de indivíduos idosos. Rev Soc Bras Fonoaudiol. [Internet journal] 2010 [Access on: January 10, 2015]; 15(1) [p. 19-25]. Available at:< http://www.scielo.br/pdf/rsbf/v15n1/06.pdf >

29. Martins A, Franco EC, Caldana ML. Developing and evaluation of a website about children's language development: portal dos bebês - desenvolvimento da linguagem. Rev. CEFAC. [Internet journal]. 2015 [access on: January, 2015]; 17(1): [159-68]. ISSN 1516-1846. Available: <http://www.scielo. br/scielo.php?script $=$ sci_issuetoc\&pid $=1516$ $184620150001 \& \operatorname{lng}=$ en\& $\mathrm{nrm}=\mathrm{iso}>$.

30. Filatro A, Piconez SCB. Design instrucional contextualizado: planejamento, elaboração e avaliação de materiais didáticos para educação a distância. In: Congresso Internacional De Educação A Distância, 11., Salvador, 2004. Anais. São Paulo: ABED, 2004. Available at: <http://www. abed.org.br/congresso2004/por/pdf/049-TC-B2. pdf>. Access on: April 24, 2016. 